\title{
Preparation and characterization of Chitosan/Collagen blends containing silver nanoparticles
}

\author{
Jonacir Novaes ${ }^{1}$, Eloi Alves da Silva Filho ${ }^{1 *}$ (D), Paulo Matheus Ferro Bernardo ${ }^{1}$ and \\ Enrique Ronald Yapuchura²
}

\author{
${ }^{1}$ Laboratório de Físico-Química, Departamento de Química, Universidade Federal do Espírito Santo, \\ Vitória, ES, Brasil \\ 'Laboratório de Materiais Carbonosos e Cerâmicos - LMC, Departamento de Física, Universidade \\ Federal do Espírito Santo - UFES, Vitória, ES, Brasil \\ *eloisilv@gmail.com
}

\begin{abstract}
This work consists of preparation of the Chitosan(CHI)/Collagen(COL) blends loaded with silver nanoparticles by method of evaporation of the solvent. This blends were characterized by Fourier transform infrared (FTIR), scanning electron microscopy (SEM) and transmission electron microscopy (TEM). The results obtained demonstrated that the mass ratio of $\mathrm{CHI} / \mathrm{COL}$ was important for the maintenance of the collagen structure since in the ratio $3: 1(\mathrm{~m} / \mathrm{m}$ of CHI/COL) decrease in the ratio between the peaks of $1235 \mathrm{~cm}^{-1}$ and $1450 \mathrm{~cm}^{-1}$, respectively. Moreover the silver nanoparticles added to the polymer matrix of the obtained chitosan had an average size of $25 \mathrm{~nm}$ confirmed by TEM for silver nanoparticle.
\end{abstract}

Keywords: chitosan, collagen, blend, silver nanoparticles.

How to cite: Novaes, J., Silva Filho, E. A., Bernardo, P. M. F., \& Yapuchura, E. R. (2020). Preparation and characterization of Chitosan/Collagen blends containing silver nanoparticles. Polímeros: Ciência e Tecnologia, 30(2), e2020015. https:// doi.org/10.1590/0104-1428.00919.

\section{Introduction}

The new nanoparticles (NPs) incorporated in natural polymer as Chitosan (CHI) and Collagen (COL) have emerged as blends with potential application due to their unique physical and chemical properties. The Chitosan is a copolymer obtained through the deacetylation of acetamide groups of chitin, which originates from the exoskeleton of crustaceans ${ }^{[1-3]}$, where the D-glucosamine $(\mathrm{GlcN})$ and $\mathrm{N}$-acetyl-D-Glycosamine (GlcNAC) groups of chitin result in the formation of this copolymer of $\beta-(1,4)$-D-glucosamine and $\beta$ - $(1,4)-\mathrm{N}$-acetyl-D-glucosamine units ${ }^{[4,5]}$. This copolymer is notable for its high bactericidal, fungicidal and bioactivity potential, which, together with its specific interactions with the extracellular matrix components and cell growth factors ${ }^{[6]}$, give it high employability in a wide range of scientific areas.

Another biopolymer, the Collagen, has been very promising in this field of research, this protein has been applied in the manufacture of bioactive membranes, as they serve as a support for cell growth, in addition to transporting drugs or releasing other substances with anti-inflammatory, antibacterial and antioxidant properties at the lesion site ${ }^{[3-5]}$. The Collagen is a fibrous protein, being the largest component of the extracellular matrix in mammals, it presents ease of combination with other materials, easy processing, hydrophilicity, low antigenicity, body absorption capacity, etc ${ }^{[7-9]}$. Based on the individual characteristics of each polymer, the associated $\mathrm{CHI} / \mathrm{COL}$ can offer a non-cytotoxic, non-allergenic, biodegradable and porous biomaterial. According with Antunes et al. ${ }^{[10]}$ in your work with Chitosan/Arginine have demonstrated that many combinations this materials shown to be promising where obtained membranes with non-cytotoxic highly porous nanostructure and with bactericidal activity in vivo with tissue regeneration ${ }^{[10]}$. Therefore the many blends formed by a combination of two polymers are of great interest in the area of biomaterials, as in the case of this study, which is of potential application. The preparation and characterization of this blends with silver nanoparticles it is a new study and and few are described in the literature, among which we highlight the most similar to what we have done but that there are differences regarding its physicochemical analysis, as the focus in on its biological and biomedical application. The studies carried out by Cardoso et al. ${ }^{[1]}$ in 2014 show three formulations of silver nanoparticles with collagen (AgNPCol) and your characterization by ultraviolet-visible spectroscopy, dynamic light scattering, X-ray diffraction and antibacterial activity in vitro and cell viability assays. Where the results showed that the its nanoparticles AgNPcol at molar ratio of 1:6 have antimicrobial activity against both Staphylococcus aureus and Escherichia coli and no toxicity to the cells.

In 2016 a study by Sionkowska et al. ${ }^{[12]}$ using chitosan and collagen blends with the addition of hyaluronic acid, a glycosaminoglycan polysaccharide present in the extracellular matrix of the skin, connective tissue obtained promising results since the addition of hyaluronic acid to the biomaterial formed by chitosan and collagen increased thermal stability, elasticity, facilitated proliferation and served as the basis for tissue regeneration, mainly cartilage tissues $^{[12]}$. In the work of Archana et al. ${ }^{[13]}$ that using chitosan, polyvinylpyrrolidone (PVP) and silver oxide nanoparticles prepared and evaluated for cytotoxicity and antibacterial 
activity against Staphylococcus aureus and Escherichia coli where they obtained satisfactory results with different concentrations of silver nanoparticles.

The aim of this work is obtained Chitosan/Collagen blends with silver nanoparticles and characterize by infrared spectroscopy (FTIR), SEM and TEM microscopy.

\section{Materials and Methods}

\subsection{Materials}

The chitosan employed, with presents a $63 \%$ deacetylation degree and a medium molar mass of $1.61 \times 10^{6} \mathrm{~g} / \mathrm{mol}^{[14]}$, was obtained in previous studies ${ }^{[15]}$. The bovine collagen, purity of $98 \%$ was provided of NovaProm ${ }^{\circledR}$ Food Ingredients. Glacial acetic acid and glutaraldehyde $25 \%(\mathrm{v} / \mathrm{v})$ both from Dinamica Chemicals.

\subsection{Experimental Procedure to preparation of Chitosan/Collage blends}

For the preparation of $\mathrm{CHI} / \mathrm{COL}$ was initially a volume of $100 \mathrm{~mL}$ of $1.5 \%(\mathrm{w} / \mathrm{v})$ solution of the polymers were prepared at $25^{\circ} \mathrm{C}$, dissolving both chitosan and collagen in $5 \%(\mathrm{v} / \mathrm{v})$ solutions of acetic acid. Then, a $10 \mathrm{~mL}$ aliquot of the chitosan solution was transferred and conditioned in erlenmeyer flask $(100 \mathrm{~mL})$, to which $1 \mathrm{~mL}$ of glutaraldehyde solution $5 \%(\mathrm{v} / \mathrm{v})$ was added. The mixture was stirred with magnetic stirrer for $30 \mathrm{~min}$, and then different aliquots of the $1.5 \%(\mathrm{w} / \mathrm{v})$ collagen solution were added. The $\mathrm{CHI} / \mathrm{COL}$ ratios were 1:1, 1:2, 2:1, 3:1 and 1:3 respectively. Stirring was continued for $2 \mathrm{~h}$ and then the polymer blend was transferred to polypropylene forms for drying at room temperature, $25^{\circ} \mathrm{C}$. After drying, the characterizations of the blends were made by infrared spectroscopy (FTIR) in the spectrophotometers FTIR 400 from Perkin-Elmer and Cary 630 from Agilent. The scanning electron microscopy (SEM) images were made using the SSX-550 SEM-EDX from Shimadzu and transmission electron microscopy (TEM) using the JEM 2100 from JEOL.

\subsection{Synthesis of Silver nanoparticles and insertion in $\mathrm{CHI} / \mathrm{COL}$ blends}

The synthesis of silver nanoparticles (AgCINP) from silver nitrate $\left(\mathrm{AgNO}_{3}\right)$ was based on the work of Loza et al. ${ }^{[16]}$ with modifications. Using the chitosan purification filtrate, obtained according to the methodology described previously ${ }^{[11]}$, where a aliquots of $50 \mathrm{~mL}$ this filtrate was removed and packed in erlenmeyer flask $(100 \mathrm{~mL})$, then added $2 \mathrm{~mL}$ of the $25 \mathrm{mmol} / \mathrm{L}$ solution of $\mathrm{AgNO}_{3}$, and stirred for $2 \mathrm{~h}$ with heating at $80^{\circ} \mathrm{C}$. Then the suspension obtained was centrifuged for $30 \mathrm{~min}$ at $5000 \mathrm{rpm}$, the supernatant was discarded and the $\mathrm{AgClNP}$ precipitate was added to chitosan solution after washed and dried at $45{ }^{\circ} \mathrm{C}$ in stove with air circulation. Finally was added $12 \mathrm{mg}$ of the AgCINP in CHI/COL blends obtained in 2.2 subsection. This polymer blend loaded with silver nanoparticles was transferred to polypropylene forms for drying at room temperature $\left(25^{\circ} \mathrm{C}\right)$ for 7 days.

\section{Results and Discussions}

\subsection{Spectra of infrared spectroscopy to $\mathrm{CHI} / \mathrm{COL}$ blend}

In the infrared spectroscopy analysis (Figure 1) the chitosan spectrum presented the axial stretching bands of O-H (between 3300 and $3400 \mathrm{~cm}^{-1}$ ), which appeared superimposed with the stretching band $\mathrm{N}-\mathrm{H}$. Also, the angular deformation of N-H (around $1550 \mathrm{~cm}^{-1}$ ) was observed, probably overlapping the axial deformation of $\mathrm{C}=\mathrm{O}$ of the amide and axial deformation of $\mathrm{C}-\mathrm{N}$ of amino groups $\left(1400 \mathrm{~cm}^{-1}\right)$. The bands of polysaccharide structures in the region of $890-1156 \mathrm{~cm}^{-1}$ in agreement with literature ${ }^{[16]}$ were observed as well.

The collagen spectrum showed the characteristic bands of amide I, II and III at 1650, 1560 and $1235 \mathrm{~cm}^{-1}$, respectively. It is also composed of vibration absorptions of $-\mathrm{CH}_{2}$ groups of the glycine skeleton and proline side chains ${ }^{\left[{ }^{[13}\right]}$. In addition, bands of 3270, 2920 and $1430 \mathrm{~cm}^{-1}$, which represent the elongation of rings $-\mathrm{OH},-\mathrm{CH}_{3}$ and pyrrolidine, respectively, were observed ${ }^{[13]}$.

The interactions between collagen and chitosan may occur through the formation of hydrogen bonds. The - $\mathrm{OH},-\mathrm{NH}_{2}$ and $-\mathrm{C}=\mathrm{O}$ groups in the collagen are capable of forming hydrogen bonds with $-\mathrm{OH}$ and $-\mathrm{NH}_{2}$ present on chitosan ${ }^{[14]}$. As reported in a previous study ${ }^{[13]}$, in a slightly acid medium occurs protonation of the amino groups of chitosan, which favors the electrostatic attraction with-COO-groups of aspartic and glutamic acid residues of collagen.

The FTIR spectra of the blends in different proportions of chitosan and collagen are observed in Figure 2, where no additional bands were identified. As previously identified in other works ${ }^{[13]}$, there is an increase of the band corresponding to amide I and decrease of amide II as the proportion of collagen increases.

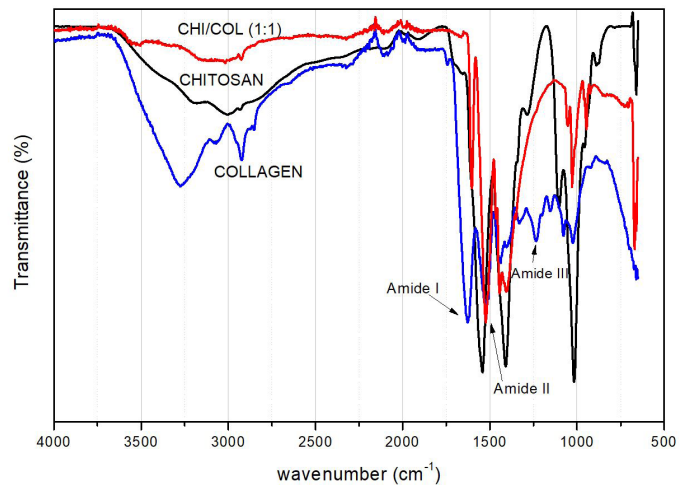

Figure 1. FTIR spectra of chitosan, chitosan/collagen (1:1), and collagen.

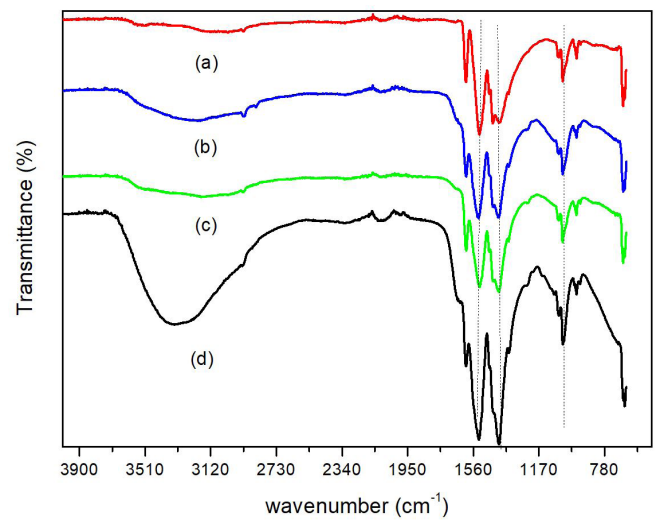

Figure 2. FTIR spectra of chitosan/collagen blends: (a) 1:1; (b) $1: 2$; (c) $1: 3$ and (d) $3: 1$. 
The integrity of the triple helix of the collagen can be evaluated by the ratio between the absorbance at 1235 and $1450 \mathrm{~cm}^{-1}[16]$. That is an very important, since this three-dimensional collagen characteristic gives it important biological and mechanical properties ${ }^{[13]}$. The values of this ratio for the denatured collagen are about 0.5 and those of intact structures are about 1 . For the samples in the proportion of $1: 1,1: 2$ and $1: 3$ chitosan/collagen, the ratios obtained were above of 1 , but for the $3: 1$ proportion the value obtained was 0.46 , which is indicative that the increase in the amount of chitosan in relation to the collagen destabilizes the triple helix of the protein structure of the collagen ${ }^{[17]}$.

\subsection{Morphological analysis to CHI/COL blend}

The Figure 3, shows the macroscopic appearance of the blends, where it can be observed that the malleability of the blends decreases with increasing chitosan. In analysis of the scanning electron microscopy (SEM), the chitosan/collagen blends showed a porous structure, with open pores and a high degree of interconnectivity between the blends phases like show in Figure 4d.

\subsection{Microscopy analysis to CHI/COL blend with Silver nanoparticles}

Transmission electron microscopy (TEM) was used to provide more information about the size, shape and morphology of the synthesized silver nanoparticles added to the chitosan polymer matrix, these micrographs (Figure 5) were treated with the image ${ }^{\circledR}$ software to obtain the size of the particles.

The TEM images revealed that the synthesized silver nanoparticles formed were predominantly spherical, polydisperse and with diameters in the range of $15-35 \mathrm{~nm}$, may also observed that the silver nanoparticles are surrounded
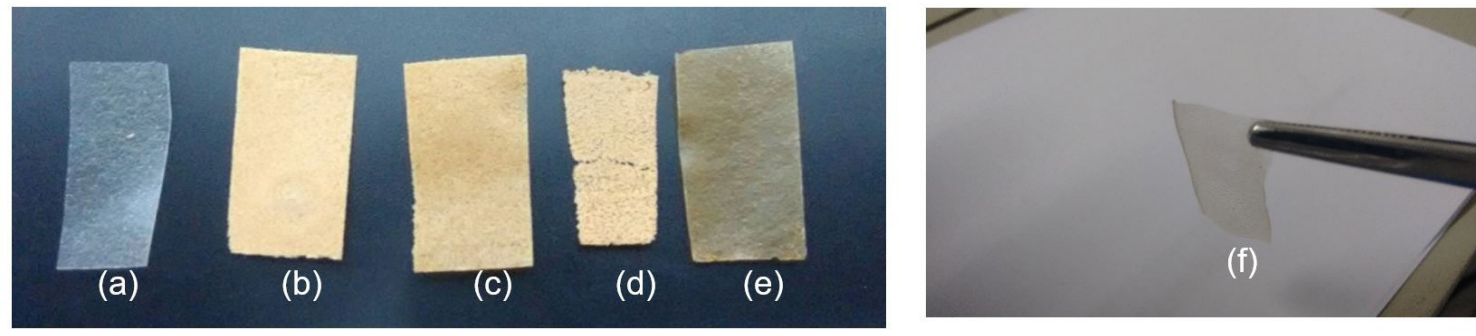

Figure 3. Macroscopic appearance of (a) collagen; and blends CHI/COL (b) (1:1); (c) (1:2); (d) (3:1); (e) (1:3) and (f) lateral view (1:1).
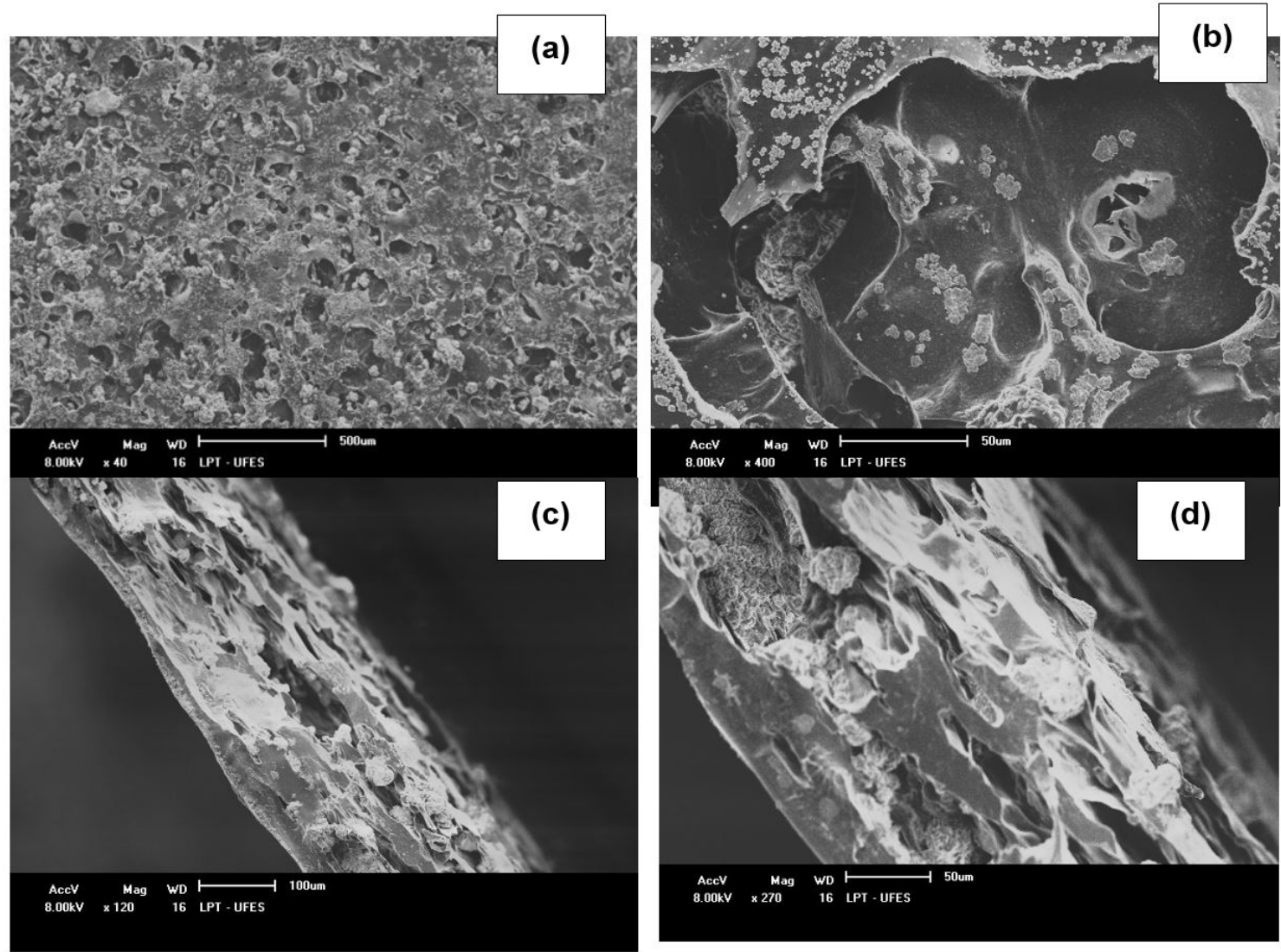

Figure 4. SEM micrographs of chitosan-collagen magnification of (a) 50x; (b) 400x; (c) cross section of 120x and (d) 270x. 

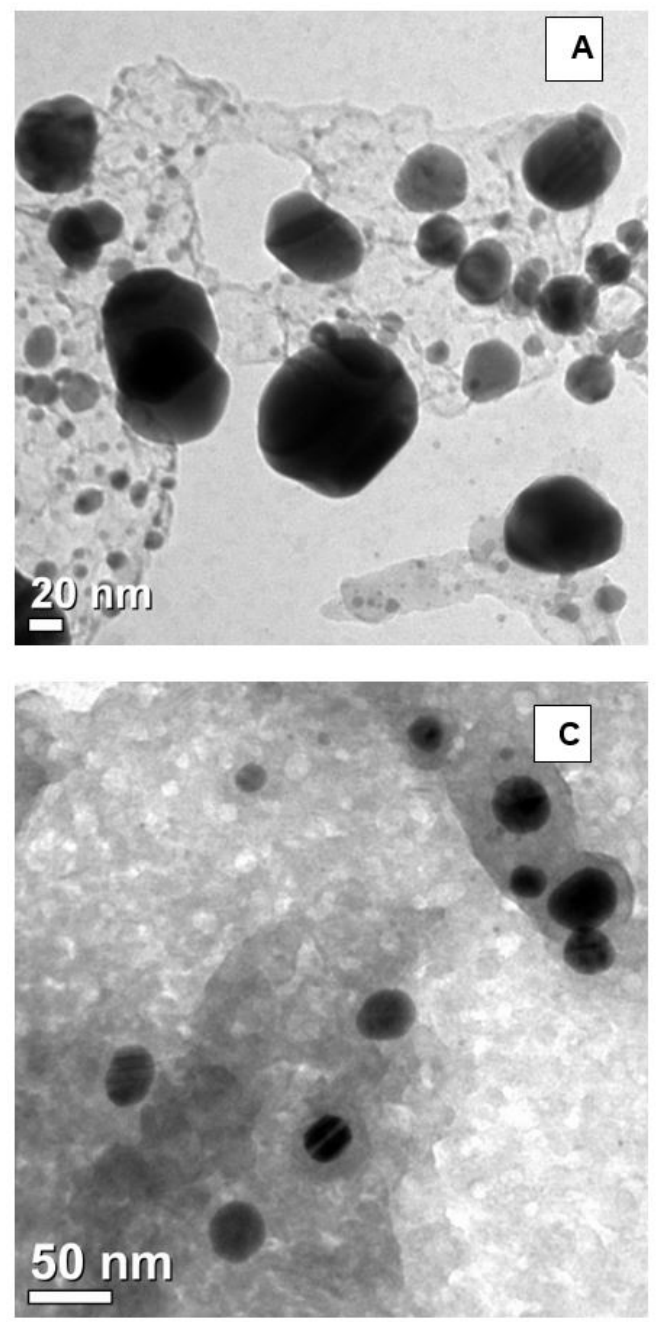

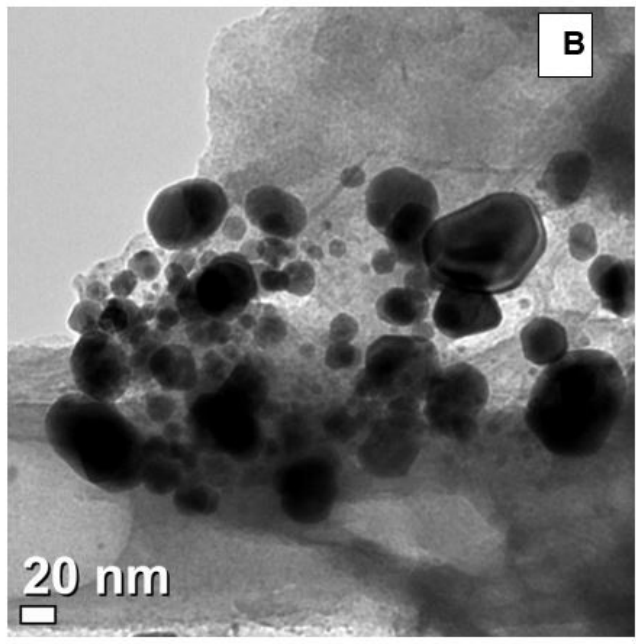

D

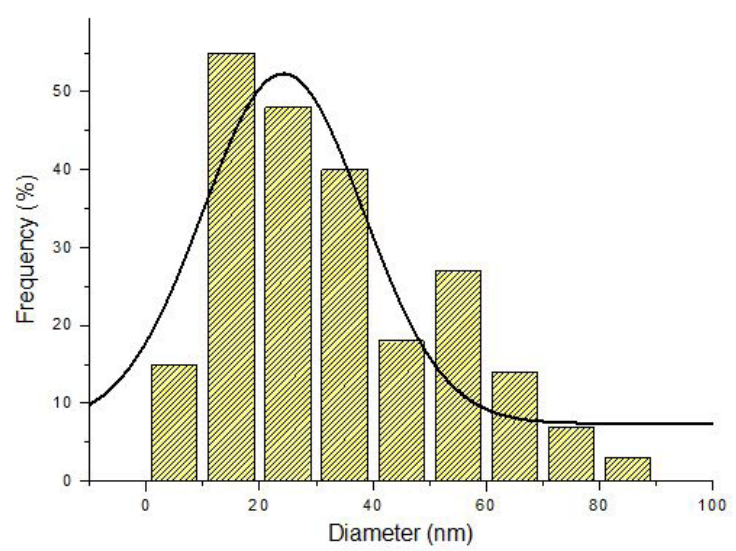

Figure 5. TEM of Silver nanoparticles adhered to CHI/COL blend: (A) and (B) in $20 \mathrm{~nm}$ scale, (B), (C) $50 \mathrm{~nm}$ scale (D) histogram to average size of the silver nanoparticles estimated by image ${ }^{\circledR}$ software.

by a thin layer of other material, which is believed be of organic material of the polymer.

These limiting organic materials prevent the aggregation of silver nanoparticles and thus provide additional stability for them, the same observation has been reported in the work of Parveen et al. ${ }^{[18]}$.

Similar micrographs to Figure 5 were obtained by Kim et al. ${ }^{[19]}$ who synthesized silver and gold nanoparticles from ginseng extract and by Shen et al. ${ }^{[20]}$ who obtained $\mathrm{AgClNP}$ by microemulsion.

The average size of the nanoparticles obtained together with the chitosan matrix was $25 \mathrm{~nm}$, the size of the nanoparticles is an important factor since the silver ions cross the membrane of the microorganism have the capacity to inhibit bacterial multiplication by the binding and denaturation of the DNA, affecting ribosomal subunit and some enzymes important for the growth of bacterial cells, hence the efficiency of this process is dependent on the size of these nanoparticles as reported in the literature ${ }^{[21]}$.

\section{Conclusions}

Using the method of phase inversion by solvent evaporation of the polymer solutions, chitosan-collagen blends were successfully produced with porous and interconnected structures confirmed in SEM, compatible with other methods used in the literature. The chitosan-collagen ratio is important for the maintenance of the collagen structure, since the ratio $3: 1$ showed a possible protein denaturation of the collagen, causing a possible loss of its properties as biomaterial. The FTIR confirmed regions in both chitosan and collagen responsible for the intermolecular interaction between the polymers that make them compatible for future use in regenerative medicine.

\section{Acknowledgments}

The authors gratefully thanks Coordenação de Aperfeiçoamento de Pessoal de Nível Superior (CAPES) for MS scholarship, the analysis by Nucleus of Competences 
in Petrochemical Chemistry (NCQP-UFES) for FTIR and the LUCCAR laboratory by SEM and TEM images of $\mathrm{CHI} / \mathrm{COL}$ blends.

\section{References}

1. Badawy, M. E. I., \& Rabea, E. I. (2011). A biopolymer chitosan and Its derivatives as promising antimicrobial agents against plant pathogens and their applications in crop protection. International Journal of Carbohydrate Chemistry, 460381, 1-29. http://dx.doi.org/10.1155/2011/460381.

2. Mi, F. L., Shyu, S. S., Wu, Y. B., Lee, S. T., Shyong, J. Y., \& Huang, R. N. (2001). Fabrication and characterization of a sponge-like asymmetric chitosan membrane as a wound dressing. Biomaterial, 22(2), 165-173. http://dx.doi.org/10.1016/ S0142-9612(00)00167-8. PMid:11101160.

3. Costa, S. (2006). Quitosana: derivados hidrossolúveis, aplicações farmacêuticas e avanços. Quimica Nova, 29(4), 776-785. http:// dx.doi.org/10.1590/S0100-40422006000400026.

4. Anitha, A., Sowmya, S., Kumar, P. T. S., Deepthi, S., Chennazhi, K. P., Ehrlich, H., Tsurkan, M., \& Jayakumar, R. (2014). Chitin and chitosan in selected biomedical applications. Progress in Polymer Science, 39(9), 1644-1667. http://dx.doi.org/10.1016/j. progpolymsci.2014.02.008.

5. Lee, D. W., Lim, C., Israelachvili, J. N., \& Hwang, D. S. (2013). Strong adhesion and cohesion of chitosan in aqueous solutions. Langmuir, 29(46), 14222-14229. http://dx.doi. org/10.1021/la403124u. PMid:24138057.

6. Sharma, C., Amit, K. D., Pravin, D. P., \& Narayan, C. M. (2015). Fabrication of quaternary composite scaffold from silk fibroin, chitosan, gelatin, and alginate for skin regeneration. Journal of Applied Polymer Science, 132(44), 42743. http:// dx.doi.org/10.1002/app.42743.

7. Shoulders, M. D., \& Raines, R. T. (2009). Collagen structure and stability. Annual Review of Biochemistry, 78(1), 929-958. http://dx.doi.org/10.1146/annurev.biochem.77.032207.120833. PMid:19344236.

8. Moraes, M. A., Silva, M. F., Weska, R. F., \& Beppu, M. M. (2014). Silk fibroin and sodium alginate blend: miscibility and physical characteristics. Materials Science and Engineering C, 40, 85-91. http://dx.doi.org/10.1016/j.msec.2014.03.047. PMid:24857469.

9. Li, J., Barrow, D., Howell, H., \& Kalachandra, S. (2010). In vitro drug release study of methacrylate polymer blend system: effect of polymer blend composition, drug loading and solubilizing surfactants on drug release. Journal of Materials Science. Materials in Medicine, 21(2), 583-588. http://dx.doi. org/10.1007/s10856-009-3899-6. PMid:19856082.

10. Antunes, B. P., Moreira, A. F., Gaspar, V. M., \& Correia, I. J. (2015). Chitosan/arginine-chitosan polymer blends for assembly of nanofibrous membranes for wound regeneration. Carbohydrate Polymers, 130, 104-112. http://dx.doi.org/10.1016/j. carbpol.2015.04.072. PMid:26076606.

11. Cardoso, V. S., Quelemes, P. V., Amorim, A., Primo, F. L., Gobo, G. G., Tedesco, A. C., Mafud, A. C., Mascarenhas, Y. P., Corrêa, J. R., Kuckelhaus, S. A. S., Eiras, C., Leite, J.
R. S. A., Silva, D., \& Júnior, J. R. S. (2014). Collagen-based silver nanoparticles for biological applications: synthesis and characterization. Journal of Nanobiotechnology, 12(36), 2-9. http://dx.doi.org/10.1186/s12951-014-0036-6. PMid:25223611.

12. Sionkowska, A., Kaczmarek, B., Lewandowska, K., Grabska, S., Pokrywczynska, M., Kloskowski, T., \& Drewa, T. (2016). 3D composites based on the blends of chitosan and collagen with theaddition of hyaluronic acid. International Journal of Biological Macromolecules, 89, 442-448. http://dx.doi. org/10.1016/j.ijbiomac.2016.04.085. PMid:27151670.

13. Archana, D., Singh, B. K., Dutta, J., \& Dutta, P. K. (2015). Chitosan-PVP-nano silver oxide wound dressing: in vitro and in vivo evaluation. International Journal of Biological Macromolecules, 73, 49-57. http://dx.doi.org/10.1016/j. ijbiomac.2014.10.055. PMid:25450048.

14. Alessandro, C. S., Silva, E. A., Fo., Coelho, E. R. C., \& Kock, F. V. C. (2015). Preparação e caracterização de blendas híbridas de Poliacrilonitrila e Quitosana. Orbital: The Electronic Journal of Chemistry, 7, 391-394. http://dx.doi.org/10.17807/orbital. v7i4.778.

15. Silva, E. A., Fo., Kock, F. V. C., \& Castro, E. V. R. (2011). BR PI 11064145. INPI.

16. Loza, K., Sengstock, S., Chernousova, S., K'oller, M., \& Epple, M. (2014). The predominant species of ionic silver in biological media is colloidally dispersed nanoparticulate silver chloride. RSC Advances, 4(67), 35290-35297. http://dx.doi. org/10.1039/C4RA04764H.

17. Horn, M. M., Martins, V. C. A., \& Plepis, A. M. G. (2009). Interaction of anionic collagen with chitosan: effect on thermal and morphological characteristics. Carbohydrate Polymers, 77(2), 239-243. http://dx.doi.org/10.1016/j.carbpol.2008.12.039.

18. Parveen, M., Ahmad, F., Malla, A. M., \& Azaz, S. (2016). Microwave-assisted green synthesis of silver nanoparticles from Fraxinus excelsior leaf extract and its antioxidant assay. Applied Nanoscience, 6(2), 267-276. http://dx.doi.org/10.1007/ s13204-015-0433-7.

19. Kim, Y., Farh, M., \& Yang, D. (2016). Biogenic silver and gold nanoparticles synthesi using red ginseng root extract, and their applications. Artificial Cells, Nanomedicine, and Biotechnology, 44(3), 811-816. http://dx.doi.org/10.3109/21 691401.2015.1008514. PMid:25706249.

20. Shen, J., Zheng, X., Ruan, H., Wu, L., Qiu, J., \& Gao, G. (2007). Synthesis of AgCl/PMMA hybrid membranes and their sorption performance of cyclohexane/cyclohexene. Journal of Membrane Science, 304(1-2), 118-124. http://dx.doi. org/10.1016/j.memsci.2007.07.022.

21. Durán, N., Marcato, P. D., Conti, R., Alves, O. L., Costa, F. T. M., \& Brocchi, M. (2010). Potential Use of Silver Nanoparticles on Pathogenic bacteria, their toxicity and possible mechanisms of action. Journal of the Brazilian Chemical Society, 21(6), 949-959. http://dx.doi.org/10.1590/S0103-50532010000600002.

Received: Mar. 04, 2019

Revised: Apr. 11, 2020

Accepted: June 17, 2020 